\title{
PRODUCTION PRACTICE, MARKET AND VALUE CHAIN STUDY OF ORGANIC APPLE OF JUMLA
}

\author{
P.N. Atreya ${ }^{1}$ and A. Kafle ${ }^{2}$
}

\begin{abstract}
This study was undertaken to explore the market and value chain of apple in Jumla and Nepaljung in January 2014. Primary and secondary data were used for this study. All together 10 respondent farmers were selected for production related data, five retailers from Jumla and Nepaljung, one wholesaler from Nepaljung and 10 consumers for market study. Highest wholesale price was observed in May/June - June/July (NRs. 145/kg) while lowest was in Sept./Oct.-Oct./Nov. (NRs. 83/kg). Similarly highest retail price (NRs. 185/ kg) was in the month of June/July and lowest (NRs. 115/Kg) was in Sept./Oct-Oct./Nov. The average farm gate price of apple is too low (NRs.26.93/ kg) as compared to wholesale, retail and consumers prices. The producers, traders, transporters, wholesalers and retailers were the main marketing actors of apple. Contractual system before and during production were observed in marketing. Price spread of Jumla apple was assessed with the different actors (contractors, traders, wholesalers, retailers and consumers) in value chain. Apple is the major commodity for income generation so better knowledge on production marketing and value addition through processing should be imparted to the farmers.
\end{abstract}

Key words: Apple, marketing channel, value chain

\section{INTRODUCTION}

Among deciduous fruits, apple is the most important crop in terms of area, production, and household economy in remote mountain districts of Nepal. Apple is a prominent and one of the important prioritized high value cash crops in the high hills of Nepal (APP, 1995). It is the fourth most extensively produced deciduous fruit crop worldwide (FAO, 2010). Largest productive area under apple in Karnali zone is found in Jumla district (2,900 ha) followed by Kalikot (1,613 ha), Mugu (950 ha), Dolpa (850 ha) and Humla (450 ha) respectively (FDD, 2015). According to MoAD (2015), export of fresh apple is $22.9 \mathrm{mt}$ (worth NRs. 83,226) to India and China while its import is about $56,447.02 \mathrm{mt}$ (worth NRs. 1,923,637,048) from China, India and USA and it indicates the high demand for this crop. Nepal government introduced apple in Jumla in 1970s and all 30 VDCs of the district have equally suitable climate for apple farming (DADO, 2012).

The general objective of the study was to know the present production situation, market and value chain of Jumla's apple and explore bottleneck areas in production and marketing of apple in Jumla through questionnaire based survey.

\section{METHODOLOGY}

Two basic approaches were adopted in conducting the study and to fulfill the objectives. First, the study had followed Systematic Secondary Information Collection and Analysis Approach (SSICA). For primary information field survey, personal interview, Participatory Rural Appraisal (PRA), Rapid Marketing Appraisal (RMA) \& Focus Group Discussion (FGD) techniques were used for obtaining information on cost of cultivation and production and supply situation of organic apple of Jumla.

\footnotetext{
${ }^{1}$ Horticulture Officer,Fruit Development Directorate, Kirtipur,Kathmandu

${ }^{2}$ Senior Vegetable Development Officer, CVSPC, Khumaltar, Nepal.
} 
Nepalgunj is the major outlet of organic apple of Jumla. So for market and value chain study wholesale market of Gurudwara and Nepalgunj retail markets were purposively selected. The population for this study was apple growers of each pocket area of Dillichour, Kartikswami, Talium and Mahatgaun where 10 respondents were randomly selected for production situation study. Similarly, five wholesalers, retailers and consumers were selected for market and value chain analysis. The obtained data were analyzed by using MS Excel program. Simple indexing technique was also used for analyzing different production and marketing related problems.

\section{RESULT AND DISCUSSION}

\section{SOCIOECONOMIC CHARACTERS OF THE RESPONDENTS}

The average age of the respondents was 46 years with family size of 6.5 persons (Table 1). The average annual income of respondents was NRs 84,500 while average landholding size was 10.3 ropani ${ }^{1}$.

Table 1: Socioeconomic characters and annual income

\begin{tabular}{|l|l|l|l|l|}
\hline S.N. & Age & Family size & Land holding (ropani) & Annual income (Rs.) \\
\hline 1 & 36 & 7 & 15 & 200000 \\
\hline 2 & 34 & 3 & 20 & 115000 \\
\hline 3 & 60 & 12 & 7 & 132000 \\
\hline 4 & 59 & 7 & 7 & 90000 \\
\hline 5 & 71 & 7 & 6 & 45000 \\
\hline 6 & 48 & 7 & 5 & 52000 \\
\hline 7 & 32 & 5 & 1 & 16000 \\
\hline 8 & 20 & 7 & 14 & 50000 \\
\hline 9 & 45 & 5 & 19 & 90000 \\
\hline 10 & 55 & 5 & 9 & 55000 \\
\hline Average & 46 & 6.5 & 10.3 & 84500 \\
\hline
\end{tabular}

Source: Field Survey, 2014.

Different types of landholding patterns like khet land, bari land and other (rangeland) were identified during the survey and average landholding of different types is presented in Table 2. The average bari land distribution was highest (4.89 ropani) followed by others including rangeland ( 4 ropani) and khet land (3.89 ropani) and average total land distribution was 10.3 ropani.

Table 2: Landholding pattern

\begin{tabular}{|l|l|l|l|l|}
\hline \multirow{2}{*}{ S.N. } & landholding in Ropani & Total \\
\cline { 2 - 5 } & Khet land & Bari land & Others (rangeland) & Tot \\
\hline 1 & 3 & 7 & 5 & 20 \\
\hline 2 & 5 & 15 & & 25 \\
\hline
\end{tabular}

\footnotetext{
${ }^{1}$ It is Nepalese unit of land area and one ha is equal to 20 ropani.
} 


\begin{tabular}{|l|l|l|l|l|}
3 & 7 & & & 7 \\
\hline 4 & 2 & 3 & 2 & 7 \\
\hline 5 & 3 & 1 & 2 & 6 \\
\hline 6 & 3 & 2 & & 5 \\
\hline 7 & & 1 & & 1 \\
\hline 8 & 4 & 3 & 7 & 14 \\
\hline 9 & 5 & 8 & 6 & 19 \\
\hline 10 & 3 & 4 & 2 & 9 \\
\hline & 3.89 & 4.89 & 4 & 10.3 \\
\hline
\end{tabular}

Source: Field Survey, 2014

Information related to duration of apple cultivation, average area, planting density, and average productivity per plant were collected from survey. Farmers were cultivating apple since 14.7 years back on an average in 5.4 ropani land with planting density of 24.45 plants per ropani (Table 3 ). Average productivity of apple was found $31.9 \mathrm{~kg} /$ plant during survey while it was $11.2 \mathrm{~kg} / \mathrm{plant}$ in DADO report (2013). The density of plant was found higher than recommended density (15 plants per ropani).

Table 3: Distribution of area and production of apple in 2013

\begin{tabular}{|l|l|l|l|l|l|}
\hline S.N. & $\begin{array}{l}\text { Years of apple } \\
\text { cultivation }\end{array}$ & Area in Ropani & $\begin{array}{l}\text { Number of plants } \\
\text { per Ropani }\end{array}$ & $\begin{array}{l}\text { Average production } \\
\text { (Kg/Plant) }\end{array}$ & $\begin{array}{l}\text { Average production } \\
\text { (kg per Ropani) }\end{array}$ \\
\hline 1 & 20 & 5 & 34 & 21 & 714 \\
\hline 2 & 15 & 4 & 11.25 & 50 & 562.5 \\
\hline 3 & 18 & 14 & 27.86 & 40 & 1114.4 \\
\hline 4 & 15 & 3 & 26 & 20 & 520 \\
\hline 5 & 20 & 6 & 27.83 & 20 & 556.6 \\
\hline 6 & 10 & 5 & 25 & 23 & 575 \\
\hline 7 & 11 & 1 & 34 & 40 & 1360 \\
\hline 8 & 5 & 7 & 13.57 & 10 & 135.7 \\
\hline 9 & 19 & 5 & 20 & 50 & 1000 \\
\hline 10 & 14 & 4 & 25 & 45 & 1125 \\
\hline Average & 14.7 & 5.4 & 24.45 & 31.9 & 766.32 \\
\hline
\end{tabular}

Source: Field Survey, 2014

Apple is the perennial crop and production varies according to age and management practices, highly productive age is 10 years onwards but production starts from 3-4 years if planting is done through grafted plants. Thus, the apple plants were grouped into 6 categories for determining distribution of plants (Figure 1). Maximum number of plants of the surveyed areas were of 1 to 5 years age (458 no.) followed by 15 to 20 (353 no.), 5 to 10 (259 no.) and 10 to 15 (234 no.). It was found that the large number of plants were recently planted after implementation of Apple Self Sufficiency Program (ASSP) and that signifies the great potentiality of expanding area through the implementation ASSP and increasing production and productivity in future. 


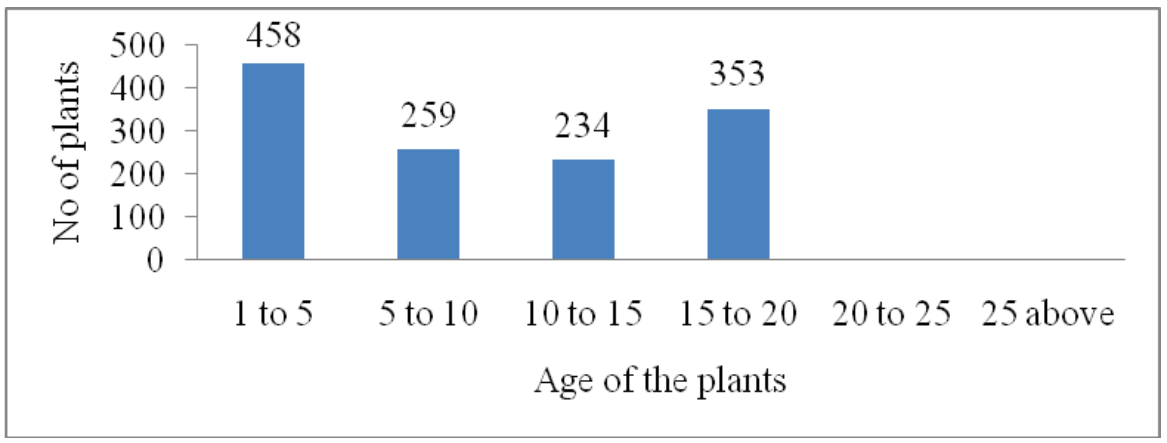

Figure 1: Age wise distribution of apple plants during 2014.

Production of apple depends on the type of sapling used (seedling origin or grafted). All the farmers were using apple saplings produced through grafting. Digging pit at least one month prior to planting and filling with compost are the most important operations. Almost all the farmers fill pit with compost and transplant saplings.

\section{INSECT PEST AND DISEASES}

The productivity of apple is dependent upon insect pest and disease situation. Apple is affected by several types of insect/pest during growth and production phase, the major ones are wooly aphid, scale, borer and caterpillar (DADO, 2013). Among the insects identified through survey, wooly aphid was the major followed by apple borer (Table 4). Similar to insect/pest disease is also major problem. Diseases such as apple scab, powdery mildew, twig blight, papery bark, and crown gall were identified in the district (DADO, 2013). Among the diseases, papery bark was the major problem followed by root rot in the respective study area (Table 5).

Table 4: Major insects/pests of study area

\begin{tabular}{|l|l|l|l|l|l|l|l|}
\hline \multirow{2}{*}{ S.N. } & & \multicolumn{2}{l|}{ Score } & & $\begin{array}{l}\text { Index } \\
\text { value } \\
(\Sigma \mathrm{fisi} / \mathrm{N})\end{array}$ & $\begin{array}{l}\text { Priority } \\
\text { ranking }\end{array}$ \\
\cline { 3 - 8 } & Major Insects & 3 & 2 & 1 & Total & 1 & I \\
\hline 1 & Wooly aphid & & & 9 & 9 & 1.88 & II \\
\hline 2 & Borer & & 8 & 1 & 17 & 1.25 & III \\
\hline 3 & Grub & 3 & & & 9 & 2.25 \\
\hline
\end{tabular}

Source: Field Survey, 2014.

Table 5: Major diseases of study area

\begin{tabular}{|l|l|c|c|c|c|c|c|}
\hline \multirow{2}{*}{ S.N. } & \multirow{2}{*}{ Major diseases } & \multicolumn{3}{|c|}{ Score } & & Index value $(\Sigma$ fisi/N) & Priority ranking \\
\cline { 3 - 6 } & 3 & 2 & 1 & Total & & \\
\hline 2 & Papery bark & & & 10 & 10 & 1 & $\mathrm{I}$ \\
\hline 3 & Root rot & & 5 & & 10 & 2 & $\mathrm{II}$ \\
\hline
\end{tabular}

Source: Field Survey, 2014. 


\section{COST OF CULTIVATION}

The production of apple depends on the levels of inputs used like labor, manure, pesticide, number of productive plants per unit area and training and pruning practices. In order to determine variable cost and items per year after the establishment of apple orchard, cost on fertilizer, insecticides, equipment, and labor cost obtained are tabulated in Table 6. As Jumla is declared as organic district, only organic fertilizers and disease and pest control practices were followed by the farmers. The average cost of cultivation per ropani was NRs. 10,718. Among the cost items, the highest cost incurred was in labor (NRs. 6,960). The per kg cost of production of apple was Rs 13.92 during survey year.

Table 6: Variable cost of cultivation of apple

\begin{tabular}{|l|l|l|l|l|l|}
\hline \multirow{2}{*}{ S.N. } & \multicolumn{5}{|c|}{ Cost of cultivation per Ropani } \\
\cline { 2 - 6 } & $\begin{array}{c}\text { Organic } \\
\text { fertilizer cost (Rs) }\end{array}$ & $\begin{array}{c}\text { Organic insecticides/ } \\
\text { fungicides (Rs) }\end{array}$ & Equipment cost(Rs) & $\begin{array}{c}\text { Labor } \\
\text { cost(Rs) }\end{array}$ & \multicolumn{1}{c|}{ Total (Rs) } \\
\hline 1 & 3400 & 2040 & 680 & 10000 & 16120 \\
\hline 2 & 1012.5 & 787.5 & 225 & 5000 & 7025 \\
\hline 3 & 2785.72 & 1671.6 & 612.92 & 8000 & 13070.23 \\
\hline 4 & 1300 & 1300 & 572 & 9000 & 12172 \\
\hline 5 & 1948.34 & 1669.8 & 556.6 & 7000 & 11174.73 \\
\hline 6 & 1625 & 1250 & 500 & 7500 & 10875 \\
\hline 7 & 2720 & 1360 & 748 & 5400 & 10228 \\
\hline 8 & 950 & 678.5 & 298.54 & 5500 & 7427.04 \\
\hline 9 & 1600 & 1100 & 460 & 6000 & 9160 \\
\hline 10 & 1875 & 1250 & 600 & 6200 & 9925 \\
\hline & 1921.65 & 1310.74 & 525.31 & 6960.00 & 10717.70 \\
\hline
\end{tabular}

Source: Field Survey, 2014.

\section{METHOD OF HARVESTING APPLE}

The farmers did not followed scientific technology recommended for harvesting apple, as hand plucking is most common practice observed in the study area (Figure 2). Shaking apple plants and use of stick is another common mode followed by the farmers.

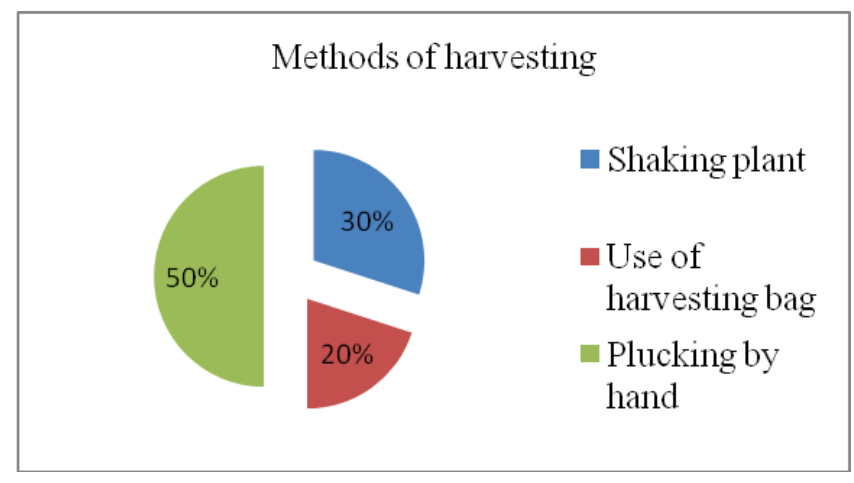

Figure2: Common methods of apple harvesting 


\section{HARVESTING AND SELLING BASIS OF APPLE}

Postharvest life of apple is dependent on the stage of harvesting. Too ripe and too green apple is not suitable for marketing. Most of the farmers harvest apple when they are $75 \%$ ripe followed by harvesting at $50 \%$ ripe stage. Weighing was the most common practice for selling apples while counting is still praciced (Table 7). Grading is not common among the farmers. Grading is done by traders and middleman. Usually, they grade apple in three categories according to size i.e. large, medium and small.

Table 7: Basis of selling of apple fruits

\begin{tabular}{|l|l|l|l|}
\hline \multirow{2}{*}{ S.N. } & Esasis of selling & Weighing \\
\cline { 2 - 4 } & Estimation & Counting & \\
\hline 1 & & 1 & \\
\hline 3 & 1 & & 1 \\
\hline 4 & & 1 & 1 \\
\hline 5 & & & 1 \\
\hline 6 & & & 1 \\
\hline 7 & & & 1 \\
\hline 8 & & & 1 \\
\hline 9 & & & 1 \\
\hline 10 & & & $7(70)$ \\
\hline & $1(10)$ & $2(20)$ & \\
\hline
\end{tabular}

Source: Field Survey, 2014

Figure in parenthesis indicates percentage MODE OF SELLING

Apple in Jumla is sold in the market through different ways. Selling to the local traders is the most common mode of selling apples (Table 8). The local traders collect apples in major collection and market centers and supply them out of the district markets like Surkhet, Nepaljung and Kathmandu too. It was found that District Cooperative Federation collects organic apples at Jumla airport and sends to Kathmandu. Large apple producers bring their produce to Surkhet and Nepalgung themselves. Some of the farmers collect other farmer's apple from their field and brings to wholesale market of Nepaljung.

Table 8: Common selling practices of apple

\begin{tabular}{|l|l|l|l|l|}
\hline \multirow{4}{*}{ S.N. } & \multicolumn{3}{|l|}{ Place of selling } \\
\cline { 2 - 5 } & $\begin{array}{l}\text { Local } \\
\text { market }\end{array}$ & $\begin{array}{l}\text { Local } \\
\text { trader }\end{array}$ & $\begin{array}{l}\text { Trader from } \\
\text { Nepalgunj }\end{array}$ & Cooperative \\
\hline 1 & & & 1 & \\
\hline 2 & & 1 & & \\
\hline
\end{tabular}




\begin{tabular}{|l|l|l|l|l|}
3 & & 1 & & \\
\hline 4 & & & & 1 \\
\hline 5 & & & & 1 \\
\hline 6 & & 1 & & \\
\hline 7 & & 1 & & \\
\hline 8 & & 1 & & \\
\hline 9 & & 1 & & \\
\hline 10 & & 1 & & \\
\hline & & $7(70)$ & $1(10)$ & $2(20)$ \\
\hline
\end{tabular}

Source: Field Survey, 2014.

INFORMATION ABOUT PRICE AND RETURN

\section{Farm gate price}

Minimum and average price of apple from August/September to December/January were analyzed. The average minimum price per $\mathrm{kg}$ was NRs. 20.0, maximum price NRs. 35 and average price was Rs 26.93 at farm gate level (Table 9).

Table 9: Average farm gate price of apple

\begin{tabular}{|l|l|l|l|}
\hline \multirow{2}{*}{ S.N. } & \multicolumn{3}{|l|}{ Farm gate price (NRs./kg) } \\
\cline { 2 - 4 } & Min. & Max. & Average \\
\hline 1 & 27.5 & 30 & 28.75 \\
\hline 2 & 15 & 35 & 25 \\
\hline 3 & 26 & 26 & 26 \\
\hline 4 & 25 & 45 & 35 \\
\hline 5 & 20 & 32 & 26 \\
\hline 6 & 25 & 30 & 27.5 \\
\hline 7 & 20 & 30 & 25 \\
\hline 8 & 15 & 25 & 20 \\
\hline 9 & 25 & 30 & 27.5 \\
\hline 10 & 26 & 31 & 28.5 \\
\hline & 22.45 & 31.4 & 26.93 \\
\hline
\end{tabular}

Source: Field Survey, 2014.

\section{CRITERIA FOR PRICE FIXATION}

Different criteria for fixing price were asked to the farmers and scoring technique was used. For fixing price most of the farmers took reference of the last year's price and quality of apple produced at their farm (Table 10). The role of trader followed by group decision were the major influencing factors for price fixation. 
Table 10: Criteria for fixing price of apple

\begin{tabular}{|l|l|l|l|l|l|l|l|l|}
\hline \multirow{2}{*}{ S.N. } & \multirow{5}{*}{ Criteria } & \multicolumn{5}{|c|}{ Score } & $\begin{array}{l}\text { Index value } \\
(\text { (fisi/N) }\end{array}$ & $\begin{array}{l}\text { Priority } \\
\text { ranking }\end{array}$ \\
\cline { 2 - 9 } & 1 & 2 & 3 & 4 & Total & \\
\hline 1 & Last year's price & 10 & & & & 10 & 1 & I \\
\hline 2 & Quality & 4 & 6 & & & 16 & 1.6 & II \\
\hline 3 & Market demand & & 4 & 5 & 1 & 27 & 2.7 & III \\
\hline 4 & $\begin{array}{l}\text { Number of fruits } \\
\text { per plant }\end{array}$ & & 2 & 8 & 38 & 3.8 & IV \\
\hline
\end{tabular}

Source: Field Survey, 2014

PROFIT ANALYSIS FROM APPLE AND OTHER AGRONOMICAL CROPS

The cost of cultivation, gross return, and profit/loss from the apple and other agronomical crops(rice and buckwheat) is presented in table 11. Cost of cultivation per ropani was lower in apple with higher return as well as profit in comparison to other possible agronomical crops in the surveyed area. The $\mathrm{B} / \mathrm{C}$ ratio is also higher showing highest potentiality of apple as high value crop over other crops.

Table 11: Profit analysis of apple and other agronomical crops in study area

\begin{tabular}{|l|l|l|l|l|l|l|l|l|}
\hline \multirow{2}{*}{ S.N. } & \multicolumn{2}{l}{ Cost/ropani } & \multicolumn{2}{l}{ Gross return/ropani } & \multicolumn{2}{l|}{ Net profit/ropani } & \multicolumn{2}{l|}{ B/C ratio } \\
\cline { 2 - 9 } & Apple & Other crops & Apple & Other crops & Apple & Other crops & Apple & Other crops \\
\hline 1 & 16120 & 6000 & 10000 & 6000 & -6120 & 0 & 0.62 & 1 \\
\hline 2 & 7025 & 10000 & 30000 & 20000 & 22975 & 10000 & 4.27 & 2 \\
\hline 3 & 13070.23 & 8000 & 28000 & 12000 & 14929.77 & 4000 & 2.14 & 1.5 \\
\hline 4 & 12172 & 15000 & 30000 & 15000 & 17828 & 0 & 2.46 & 1 \\
\hline 5 & 11174.73 & 20000 & 55000 & 30000 & 43825.27 & 10000 & 4.92 & 1.5 \\
\hline 6 & 10875 & 25000 & 30000 & 25000 & 19125 & 0 & 2.76 & 1 \\
\hline 7 & 10228 & 6000 & 15000 & 3000 & 4772 & -3000 & 1.47 & 0.5 \\
\hline 8 & 7427.04 & 15000 & 35000 & 20000 & 27572.96 & 5000 & 4.71 & 1.33 \\
\hline 9 & 9160 & 8000 & 20000 & 8000 & 10840 & 0 & 2.18 & 1 \\
\hline 10 & 9925 & 7500 & 22000 & 8000 & 12075 & 500 & 2.22 & 1.07 \\
\hline & 10717.7 & 12050 & 27500 & 14700 & 16782.3 & 2650 & 2.78 & 1.19 \\
\hline
\end{tabular}

Source: Field Survey, 2014

This table shows that the cost of cultivation of apple per ropani is lower than other agronomical crops while return is higher with $\mathrm{B} / \mathrm{C}$ ratio of 2.78 .

PROBLEM ANALYSIS

\section{Production problems}

Apple production in Jumla is limited by several biotic and abiotic factors. Among abiotic factor of production, training followed by the inadequacy of subsidy on production inputs like saplings and training and pruning equipments were the major problems of apple production identified through survey (Table 12). 
Table 12: Major Problems of apple production in Jumla district

\begin{tabular}{|c|c|c|c|c|c|c|c|c|c|}
\hline \multirow[b]{2}{*}{ S.N. } & \multirow[b]{2}{*}{$\begin{array}{l}\text { Major problems of } \\
\text { apple production }\end{array}$} & \multicolumn{5}{|c|}{ Score } & \multirow[b]{2}{*}{ Total } & \multirow{2}{*}{$\begin{array}{l}\text { Index value } \\
(\Sigma \mathrm{fisi} / \mathrm{N})\end{array}$} & \multirow{2}{*}{$\begin{array}{l}\text { Priority } \\
\text { ranking }\end{array}$} \\
\hline & & 1 & 2 & 3 & 4 & 5 & & & \\
\hline 1 & Training & 5 & 5 & & & & 15 & 1.5 & I \\
\hline 2 & Subsidy & 5 & 3 & 1 & & 1 & 19 & 1.9 & II \\
\hline 3 & Storage & 3 & 3 & 4 & & & 21 & 2.1 & III \\
\hline 4 & Grading/packaging & & 1 & 4 & 3 & 2 & 35 & 3.5 & IV \\
\hline 5 & Transportation & & & 1 & 5 & 4 & 41 & 4.1 & $\mathrm{~V}$ \\
\hline
\end{tabular}

\section{MARKETING PROBLEMS}

Appearance related problems (sooty mold in fruits) as a major marketing problem as Jumla is declared as organic district followed by lack of proper grading.

Table 13: Major marketing problems of apple

\begin{tabular}{|c|c|c|c|c|c|c|c|c|c|}
\hline \multirow[b]{2}{*}{ S.N. } & \multirow[b]{2}{*}{ Marketing problems } & \multicolumn{5}{|c|}{ Score } & \multirow[b]{2}{*}{ Total } & \multirow{2}{*}{$\begin{array}{c}\text { Index value } \\
(\Sigma \text { fisi/N) }\end{array}$} & \multirow[t]{2}{*}{$\begin{array}{l}\text { Priority } \\
\text { ranking }\end{array}$} \\
\hline & & 1 & 2 & 3 & 4 & 5 & & & \\
\hline 1 & Appearance & 4 & 1 & & & & 6 & 1.2 & $\mathrm{I}$ \\
\hline 2 & Lack of grading & 1 & 2 & 2 & & & 11 & 2.2 & II \\
\hline 3 & Poor packaging & & 2 & 2 & 1 & & 14 & 2.8 & III \\
\hline 4 & Poor keeping quality & & & 1 & 4 & & 17 & 3.8 & IV \\
\hline 5 & Poor taste & & & & & 5 & 25 & 5 & V \\
\hline
\end{tabular}

Source: Field Survey, 2014

\section{INFORMATION ON PRICE}

Price analysis was done based on the information obtained from the wholesalers and retailers of Jumla and Nepalgunj. The traders of Nepalgunj sell apple produced in Jumla from August/September to December/January, in other time they sell apple imported from China and India. The major hike in price was observed from February/March to July/August).

\section{WHOLESALE PRICE}

The wholesale price analysis was done based on the information obtained from the wholesalers of Nepalgunj and Jumla. The average wholesale price per $\mathrm{kg}$ was NRs. 117.8 (Table 14). Highest wholesale price was observed in May to June/July (NRs. 145/kg) while lowest was in September to November (NRs. 83/kg).

Table 14: Analysis of wholesale price of apple

\begin{tabular}{|c|c|c|c|c|c|c|c|c|c|c|c|c|c|}
\hline \multirow[b]{2}{*}{ S.N. } & \multicolumn{12}{|c|}{ Wholesale price (Rs/Kg) } & \multirow[b]{2}{*}{ Average } \\
\hline & Sept/Oct & Oct/Nov & Nov/Dec & Dec/Jan & $\mathrm{Jan} / \mathrm{Feb}$ & Feb/Mar & $\mathrm{Mar} / \mathrm{Apr}$ & Apr/May & May/June & June/July & July/Augu & Augu/Sept & \\
\hline 1 & 140 & 140 & 140 & 150 & 150 & 160 & 170 & 180 & 180 & 180 & 180 & 170 & 161.6 \\
\hline 2 & 70 & 70 & 150 & 150 & 120 & 130 & 130 & 130 & 130 & 140 & 130 & 90 & 120 \\
\hline 3 & 100 & 100 & 100 & 100 & 100 & 110 & 110 & 120 & 120 & 110 & 70 & 70 & 100.8 \\
\hline 4 & 55 & 55 & 100 & 100 & 100 & 150 & 150 & 150 & 150 & 150 & 55 & 55 & 105.8 \\
\hline \multirow[t]{2}{*}{5} & 50 & 50 & 75 & 110 & 110 & 135 & 140 & 140 & 145 & 145 & 54 & 54 & 100.6 \\
\hline & 83 & 83 & 113 & 122 & 116 & 137 & 140 & 144 & 145 & 145 & 97.8 & 87.8 & 117.8 \\
\hline
\end{tabular}

Source: Field Survey, 2014 
RETAIL PRICE

For analyzing retail price, interview with retailers of Jumla and Nepalgunj was carried out. The average retail price per $\mathrm{kg}$ was NRs. 153.5 (Table 15). Highest retail price was in the month of June/July (NRs. 185/kg) while lowest was in September to November (NRs. 115/kg).

Table 15: Analysis of retail price of apple

\begin{tabular}{|c|c|c|c|c|c|c|c|c|c|c|c|c|c|}
\hline \multirow[b]{2}{*}{ S.N. } & \multicolumn{12}{|c|}{ Retail price (Rs/kg) } & \multirow[b]{2}{*}{ Average } \\
\hline & Sept/Oct & Oct/Nov & Nov/Dec & Dec/Jan & $\mathrm{Jan} / \mathrm{Feb}$ & $\mathrm{Feb} / \mathrm{Mar}$ & Mar/Apr & Apr/May & May/June & June/July & July/Augu & Augu/Sept & \\
\hline 1 & 170 & 170 & 170 & 185 & 185 & 185 & 240 & 240 & 240 & 240 & 240 & 200 & 205.42 \\
\hline 2 & 90 & 90 & 180 & 180 & 180 & 160 & 175 & 160 & 175 & 180 & 160 & 100 & 152.5 \\
\hline 3 & 120 & 120 & 120 & 130 & 130 & 130 & 140 & 140 & 140 & 140 & 100 & 100 & 125.83 \\
\hline 4 & 80 & 80 & 120 & 120 & 120 & 180 & 180 & 180 & 180 & 180 & 75 & 75 & 130.83 \\
\hline & 115 & 115 & 147.5 & 153.7 & 153.7 & 163.7 & 183.7 & 180 & 183.7 & 185 & 143.75 & 118.7 & 153.6 \\
\hline
\end{tabular}

Source: Field Survey, 2014

CONSUMERS' PRICE

Direct interview with consumers of Jumla and Nepalgunj was carried out to analyze consumer price. Semi structured questionnaire was administered and information were obtained through recall basis for getting yearly price information. The average consumers price per kg was NRs. 160.50 (Table 16). Highest consumers price was in the month of June/July (NRs. 193/kg) while lowest was in September to November (NRs. 118.75/kg).

Table 16: Analysis of retail price of apple

\begin{tabular}{|c|c|c|c|c|c|c|c|c|c|c|c|c|c|}
\hline \multirow[b]{2}{*}{ S.N. } & \multicolumn{12}{|c|}{ consumer's price (Rs/kg) } & \multirow[b]{2}{*}{ Average } \\
\hline & Sept/Oct & Oct/No v & Nov/Dec & $\mathrm{Dec} / \mathrm{Jan}$ & $\mathrm{Jan} / \mathrm{Feb}$ & $\mathrm{Feb} / \mathrm{Mar}$ & $\mathrm{Mar} / \mathrm{Apr}$ & Apr/May & May/June & June/July & July/Augu & Augu/Sept & \\
\hline 1 & 170 & 175 & 175 & 190 & 190 & 190 & 242 & 250 & 244 & 245 & 250 & 210 & 210.92 \\
\hline 2 & 95 & 96 & 188 & 185 & 185 & 170 & 180 & 165 & 180 & 185 & 165 & 110 & 158.67 \\
\hline 3 & 125 & 127 & 128 & 135 & 135 & 140 & 145 & 145 & 145 & 150 & 110 & 110 & 132.92 \\
\hline 4 & 85 & 90 & 125 & 130 & 128 & 185 & 187 & 187 & 195 & 192 & 84 & 86 & 139.50 \\
\hline & 118.75 & 122 & 154 & 160 & 159.5 & 171.25 & 188.5 & 186.75 & 191 & 193 & 152.25 & 129 & 160.50 \\
\hline
\end{tabular}

Source: Field Survey, 2014

\section{MARKETING CHANNEL OF APPLE PRODUCED IN JUMLA}

The farm product which reaches to the ultimate consumers through the hands of various marketing agents is called the marketing channels. Marketing channel helps to determine price. Higher the numbers of marketing players, higher will be the price and vice versa. Market itself organized the intermediaries so that market functions well.

The invisible roles of the intermediaries are organized by market. The farm products of districts are brought to collection center through marketing agents or farmers themselves or group of farmers or cooperatives. From pocket areas through the road heads and hubs it is brought to Jumla, Surkhet, Banke and Bardiya and other market centers for sale.

Then from district centered market these fruit are sold to retailer, bicycle vendor, brokers, schools, hotels/restaurants, and distant wholesaler and also to exporters. In these case also various marketing agencies or middlemen are involved. The retailer to consumers and sometimes directly from wholesale markets the fruit gets into the hand of consumers but most of the time small vendors and bicycle vendors walk to door to door to sale these apple and ultimately reaches in the hand of

consumers. Figure 3: Marketing channel of organic apple of Jumla 


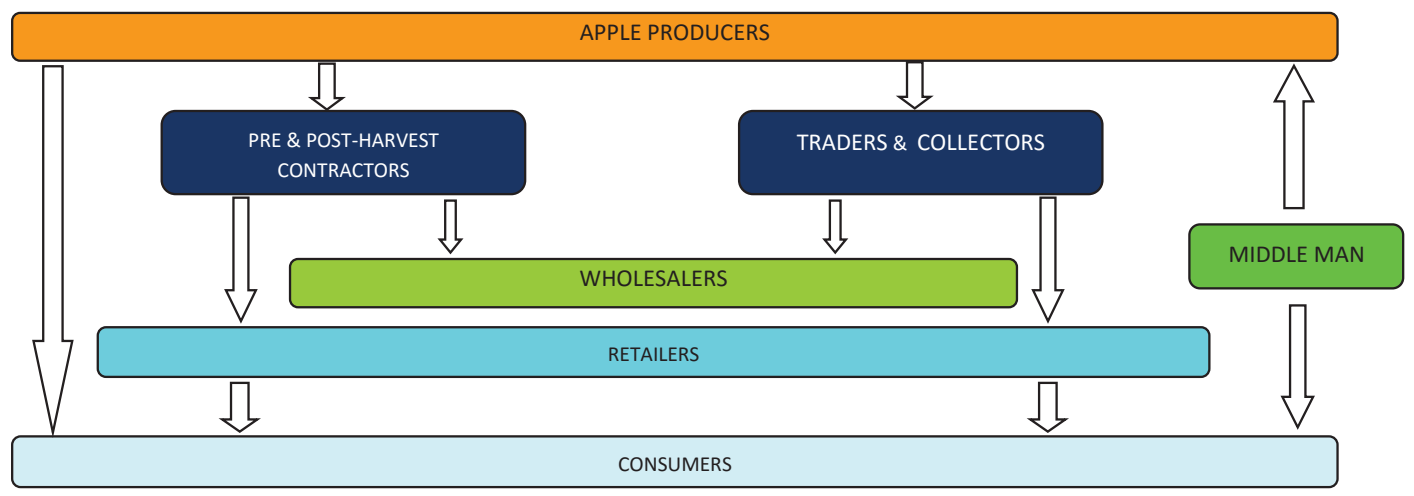

Source: Field Survey, 2014

Marketing of apple encompasses all the activities being performed in moving apple from producers to the hands of ultimate consumers. Marketing system creates time, space and form utilities of the farm produce for the consumers. The producers, traders, transporters, wholesalers and retailers were the main marketing actors of apple (Adhikari, 2011).

VALUE CHAIN STUDY OF APPLE PRODUCED IN JUMLA

Jumla is the leading district of Karnali zone for producing apples. Annually more than 12,00,000 grafted saplings of apples are produced from 103 nurseries. Agro-vets and private nursery as well as Rajikot Farm in Jumla are the major actors of sapling supply in the district. Farmers group, cooperatives and individual farmers are involved in production. The entire value chain of apple including functions, primary actors and support organization is enlisted in figure 4.

\section{VARIETIES}

There were about 10 varieties of apples being cultivated in Jumla-mostly the delicious varieties: Red, Royal and Golden Delicious. This constituted approximately $80 \%$ of the total production. The rest included Jonathan, Chocolate and Macintosh varieties.

\section{TRADE AND MARKETING OF JUMLA APPLE}

Producers directly sell apple to consumers in Jumla headquarter but large apple producers bring their produce to Surkhet and Nepalgunj themselves. Growers, especially in Talium belt-who collect from other farmers as well and send the produce to the Nepaljung's wholesalers as well as retailers.

\section{APPLE PROCESSING}

Several enterprises - including the largest called RN Organic-have started production of dried apple slice on a commercial scale, both for local consumption and export out of the district to major markets in Nepal. Similarly, RK Distillery in Jumla has started producing apple brandy. The general opinion is that dried apple has the most potential (lightweight) but they have to compete with the good quality apples coming from Mustang. 
PRICE SPREAD OF JUMLA APPLE ALONG THE VALUE CHAIN (2014)

Price spread of Jumla apple was assessed with different actors in value chain. Farmers were getting very low price of NRs. 26.93 per $\mathrm{kg}$ of their apple while the consumer's price was NRs. 160.5 per kg.

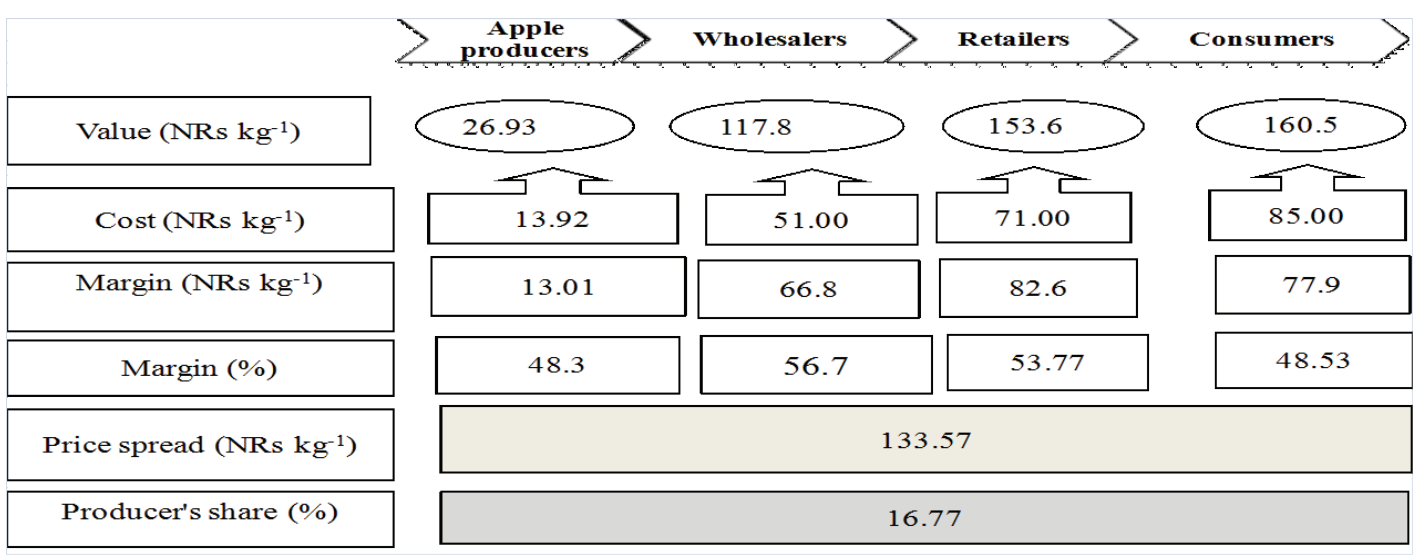

Figure 4: Price spread of Jumla apple along the value chain

There is a wide gap between farm gate price and consumer's price. Both cost involved in post harvest handling and margin of different actors was high. Producers share in consumer's price was only 16.77 percent.

\section{SUMMARY, CONCLUSION AND RECOMMENDATION}

\section{SUMMARY}

Apple is the important commodity for food security through income generation in Jumla district. Apple is grown in all 30 VDCs of Jumla district and is the major high value commodity. Most of the farmers residing in the districts are engaged in apple cultivation. Apple is the major source of income generation as most of the farmers are actively engaged in apple production. The return of apple is higher than other commodities cultivated in the district. Insect and pest especially the wooly aphid, and borer and papery bark were the major problems for the production whereas The price fixation was major marketing problems of the farmers. The major marketing problem was poor appearance of apple in the market followed by lack of grading. The average farm gate, wholesale and retail price of apple in Jumla were found NRs. 26.93, NRs. 117.8, and NRs. 153.6 respectively. Apple produced in Jumla is supplied to the Nepalgunj only from August_to November , in other season demand of apple is fulfilled by the supply from China and India.

\section{CONCLUSION}

Apple is the important source of income generation for the farmers. Most of the farmers are engaged in its cultivation due to its uniqueness, price and taste. Apple produced in Jumla is organic in nature and the demand is high in Nepalgunj but due to the lack of proper storage, market demand is not 
fulfilled by the apple from Jumla. There is the huge potentiality for organic apple production in Jumla through coordinated approaches from different stakeholders and agencies.

\section{RECOMMENDATIONS}

$>$ Training for appropriate production packages and post harvest handling of apple should be done in a coordinated way through stakeholders like DADO, NGO's and INGO's mobilizing the groups and cooperatives.

$>$ Quality improvement is necessary for better price. Thus proper harvesting techniques, picking up the produce in right time without affecting the productivity in the next year is prominent and the action plans from the extension agencies are to be prepared and implemented.

$>$ Horizontal and vertical linkages between and amongst the production, marketing and processing industries and integration among them are needed to enhance the value chain linkages so as to fetch higher return.

\section{REFERENCES}

Adhikari, J., 2011. Economics of Organic Apple Production in Jumla District. Master's Thesis. Institute of Agriculture and Animal Science, IAAS, TU, Rampur, Nepal

APP, 1995. Nepal agriculture perspective plan, APROSC and JMA Inc. National Planning Commission Secretariat, Singa Durbar, Kathmandu, Nepal. 66p.

DADO, 2013. Annual Agriculture Development Program and Statistics. Ministry of Agricultural Development, Department of Agriculture. District Agriculture Development Office, Khalanga, Jumla.

DDC, 2009. Jumla District Profile. Information and documentation center.

FAO, 2010. Statistical database. Retrived from http://www.fao.org in $7^{\text {th }}$ june, 2014.

Kafle, A., and P. N. Atreya. 2013. Apple cultivation. Fruit Development Directorate, Department of Agriculture, Ministry of Agricultural Development, Kathamandu.

Kaini, B.R. and P.B. Singh. 1998. Status of Horticulture Marketing Research and Extension in Private and Public Sectors. In: Proceeding of the National Seminar on Fruits and Vegetable Marketing in Nepal, Kathmandu, September 15-16, 1998. FAO, Kathmandu, Nepal.

MoAD, 2014. Selected indicators of Nepalese agriculture and population. Ministry of Agriculture and Cooperatives, Agribusiness Promotion and Statistical Division and Gender Equity and Environment Division. Singh Durbar, Kathmandu, Nepal.

Rana, A, 2007. Orthodox tea in Nepal upgrading with value chain approach. GTZ/PSP- RUFIN, Kathmandu, Nepal.

SNV, 2011. Value chain analysis of apple from Jumla. Ministry of agriculture and cooperatives, and Netharland development organization, Lalitpur, Nepal. 